\title{
VIDEO SURVEILLANCE OF NESTING CLAY-COLORED THRUSHES IN SOUTH TEXAS
}

\author{
JORDAN C. GIESE, JARED D. HALL, and HEATHER A. MATHEWSON, Depart- \\ ment of Wildlife, Sustainability, and Ecosystem Sciences, Tarleton State University, \\ Box T-0050, Stephenville, Texas 76402; jgiese@iastate.edu
}

Along the lower Rio Grande in Texas, an estimated 95\% of native vegetation has been destroyed through urban and agricultural expansion, leaving only isolated remnants of once continuous woodland (Jahrsdoerfer and Leslie 1988). Although some bird species have declined because of habitat loss and alteration, other species have increased. In recent decades, the Clay-colored Thrush (Turdus grayi) has expanded its range north into south Texas and is now considered common in the lower Rio Grande valley (Brush and Conway 2012), a subtropical region comprising the state's four southernmost counties.

The increase of the Clay-colored Thrush in the lower Rio Grande valley coincides with the increasing urbanization of the region. From 1993 to 2003, urbanization of Cameron, Hidalgo, and Willacy counties increased by an average of 46\% (Huang and Fipps 2011). Brush (2000) hypothesized that the continued growth of urban vegetation provides the Clay-colored Thrush with more suitable nesting sites. Major cities to the north, such as Corpus Christi and San Antonio, seem to provide vegetation suitable for breeding as well, but it is unclear if food resources and winter climate will allow colonization (Brush and Conway 2012). By the early 2000s, the Clay-colored Thrush had already expanded upriver to Laredo, Webb County (Brush and Conway 2012). Despite the increase in south Texas, little research has been devoted to the species' nesting ecology where it has already become established.

During the summer of 2016, we studied the nest ecology, survival, and longevity of the White-tipped Dove (Leptotila verreauxi) at Estero Llano Grande State Park, Hidalgo County, Texas (Giese 2016, Giese et al. 2018). While searching for dove nests, we located a Clay-colored Thrush nest, cued by the adults' behavior. Estero Llano Grande is a 97-hectare publically accessible park located roughly $7 \mathrm{~km}$ north of the Rio Grande. The park is made up of restored wetlands, shrublands, and remnant woodlands.

The thrush nest was positioned $4.2 \mathrm{~m}$ above the ground in a live oak (Quercus virginiana). Upon locating the nest, we deployed a camera system similar to that described by Cox et al. (2012) to monitor parental behavior. Our camera system comprised a continuously recording infrared-emitting camera and digital video recorder, powered by a 12 -volt marine battery housed in a plastic tote. We changed the secure digital (SD) card in the camera system every 2 or 3 days and checked the camera's position by means of a video monitor with a liquid-crystal display.

After retrieving the SD cards, we transferred the video recordings to an external hard drive for later viewing in Microsoft Windows Media Player. Once nest monitoring was complete, we watched all the video to quantify parental behavior. We developed a time budget for the nest and recorded the time each parent took a recess, the amount of time elapsed during a recess, feeding of the nestlings, and disturbances. We distinguished between the sexes by differences in behavior and parental responsibilities.

We monitored the nest from 4 July to 12 July 2016 and obtained 189 hours of video. Monitoring began with three eggs in the nest and terminated after predation by Tawny Crazy Ants (Nylanderia fulva) following the hatching of the second egg.

As found by Sanchez et al. (2018), both adults contributed to parental care. During incubation, the nest was attended primarily by the presumed female (Figure 1A), while the presumed male was often observed near the nest to defend it from predators. Incubation was fairly consistent as the female incubated throughout the night and 


\section{NOTES}
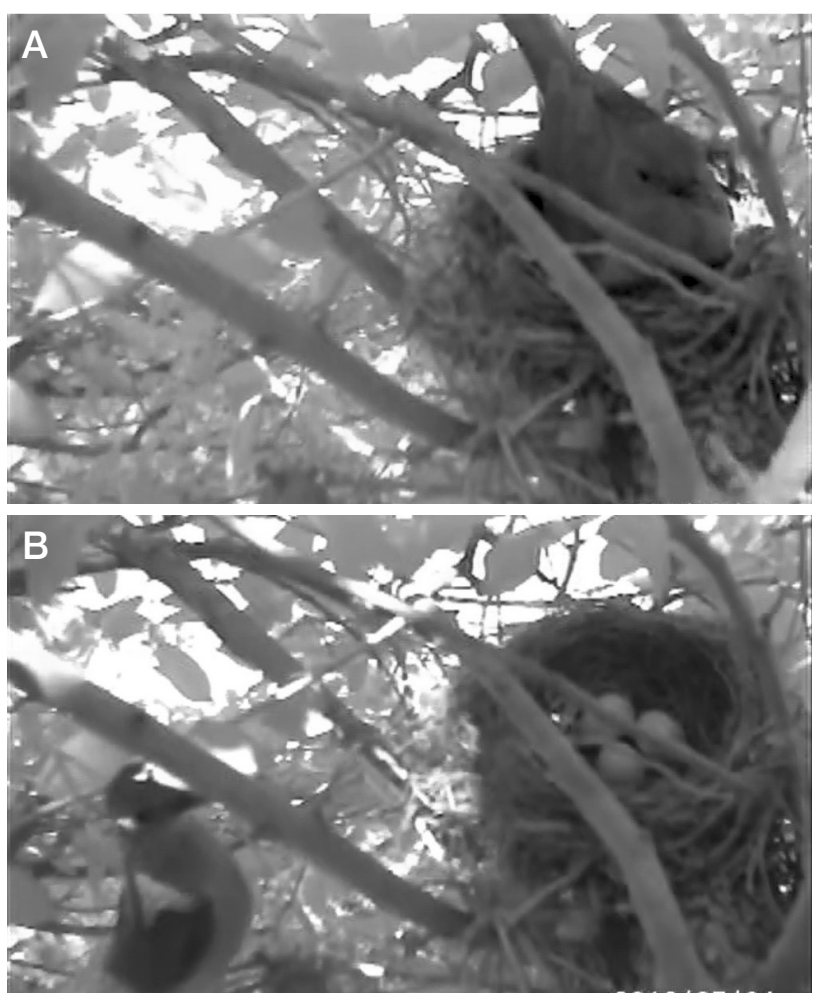

Figure 1. (A) Presumed female Clay-colored Thrush incubating eggs at nest in Estero Llano Grande State Park on 4 July 2016. (B) Presumed male perching near the nest on 4 July 2016.

Photos from continuously running video recorder

awaited arrival of the male before taking a recess. Those recesses occurred on average every $40.32 \mathrm{~min}$ (SD [standard deviation] = $11.42 \mathrm{~min}, n=76$ ) and lasted 6.91 min $(\mathrm{SD}=2.67 \mathrm{~min}, n=76)$. The female's recesses typically began each morning at dawn ( 06:30 Central Standard Time) upon the arrival of the male, although we documented recesses beginning as early as 03:35. Her recesses continued intermittently until dusk ( 20:30), when she returned to incubate for the night.

Following hatching of the first egg, the female carried off all shell fragments. She then made foraging flights at intervals similar to those observed during incubation. After hatching, the female took recesses every $41.70 \mathrm{~min}(\mathrm{SD}=10.18 \mathrm{~min}, n=21)$ for an average $6.32 \mathrm{~min}(\mathrm{SD}=1.51 \mathrm{~min}, n=21)$. The male augmented nestling feeding by delivering the brooding female unidentified insects, which she then fed to the nestling. During the female's longer recesses, the male perched on the rim of the nest until she returned (Figure 1B), occasionally feeding the nestling. Upon pipping of the second egg, Tawny Crazy Ants infested the nest and preyed on the pipping egg and on the previously hatched nestling. Shortly after the ants' predation, the parents departed, returned the next morning, and carried away the remaining intact egg. 


\section{NOTES}

In addition to food items parent thrushes brought to the nest, they also ingested unidentified prey items opportunistically as they entered the vicinity of nest. We could identify prey only superficially, as spiders, mosquitoes, and gnats. Although this nest failed, the Clay-colored Thrush is expected to continue to increase in south Texas as urbanization continues. Our observations of parental care in the Clay-colored Thrush are similar to those reported by Sanchez et al. (2018), but our use of video surveillance allowed for more thorough inspection of parental care at a single nest as well as the positive identification of a nest predator.

We made these observations during research supported by Texas Parks \& Wildlife and Tarleton State University. We thank Estero Llano Grande State Park for kindly hosting our research. Kelton Mote and Daniel "Chuck" Wilcox provided field assistance.

\section{LITERATURE CITED}

Brush, T. 2000. Nesting of Rose-throated Becard (Pachyramphus aglaiae) and Claycolored Robin (Turdus grayi) in Hidalgo County, Texas. Tex. J. Sci. 52:165-168.

Brush, T., and Conway, T. 2012. Range expansion of Clay-colored Thrush (Turdus grayi) in Texas. N. Am. Birds 65:700-703.

Cox, W. A., Pruett, M. S., Benson, T., Chiavacci, S. J., and Thompson, F. R. III. 2012. Development of camera technology for monitoring nests, in Video Surveillance of Nesting Birds (F. R. Ribic, F. R. Thompson III, and P. J. Pietz, eds.), pp. 185-198. Studies in Avian Biology 43. Univ. Calif. Press, Berkeley.

Giese, J. C. 2016. Factors influencing nest survival of White-tipped Doves in the lower Rio Grande valley, Texas. Master's thesis, Tarleton State Univ., Stephenville, TX.

Giese, J. C., Oldenburger, S. L, Mathewson, H. A., Schwertner, T. W., and Breeden, J. B. 2018. Survival and longevity of a White-tipped Dove (Leptotila verreauxi) population in south Texas. Wilson J. Ornithol. 130:996-999; doi 10.1676/1559-4491.130.4.996.

Huang, Y., and Fipps, G. 2011. Landsat satellite multi-spectral classification of land cover change for GIS-based urbanization analysis in irrigation districts: Evaluation in the lower Rio Grande valley. Texas A\&M Univ., College Station.

Jahrsdoefer, S. E., and Leslie, D. M., Jr. 1988. Tamaulipan brushland of the lower Rio Grande valley of south Texas: Description, human impacts, and management options. U.S. Fish and Wildlife Service Biol. Rep. 8836.

Sanchez, N. V., Vargas-Castro, L., and Barrantes, G. 2018. Nestling feeding, nest success, and notes of parental care in the Clay-colored Thrush (Turdus grayi): The role of females and males. Wilson J. Ornithol. 130:437-444; doi 10.1676/17-002.1.

Accepted 8 April 2019 